\title{
Estrogen-like Response of Perfluorooctyl iodide in Male Medaka (Oryzias latipes) Based on Hepatic Vitellogenin Induction
}

\author{
Yichen Wang, Qunfang Zhou, Chang Wang, Nuoya Yin, Zhuona Li, Jiyan Liu, Guibin Jiang \\ State Key Laboratory of Environmental Chemistry and Ecotoxicology, Research \\ Center for Eco-Environmental Sciences, Chinese Academy of Sciences, \\ Beijing 100085, People's Republic of China
}

Received 6 April 2011; revised 1 June 2011; accepted 4 June 2011

\begin{abstract}
Using the in vivo male medaka model, we investigated the estrogen-like response of perfluorooctyl iodide (PFOI) which is a potential source of perfluorinated carboxylic acids. Using real-time quantitative polymerase chain reaction, the expression levels of related estrogenic genes including estrogenic receptor $\alpha(E R \alpha), E R \beta$, vitellogenin I (VTG I), and VTG II in the livers of male medaka exposed to PFOI were analyzed. The results showed that PFOI upregulated the expression levels of the tested genes in a dose-dependent manner. VTG protein levels increased in both dose- and time-dependent manners due to PFOI exposure. The results suggested that PFOI is a potential estrogenic compound. (c) 2011 Wiley Periodicals, Inc. Environ Toxicol 28: 571-578, 2013.
\end{abstract}

Keywords: perfluorooctyl iodide; vitellogenin; estrogenic effects

\section{INTRODUCTION}

Worldwide attention is being paid to polyfluorinated compounds (PFCs), which consist of fluorine-containing chemicals with unique properties such as hydrophobicity and oleophobicity. Due to these attractive properties, PFCs have been mass produced and used in a wide range of consumer and industrial products including wetting agents, corrosion inhibitors, lubricants, insecticides, cosmetics, fire retardants, paper coatings, surfactants, and vinyl polymer-

\footnotetext{
Correspondence to: G. Jiang; e-mail: gbjiang@rcees.ac.cn

Contract grant sponsor: National Science and Technology Ministry of China

Contract grant number: 2007 BAC27B02-1a

Contract grant sponsor: Natural Science Foundation

Contract grant number: B20977100

Contract grant sponsor: National High Technology Research and Development Program of China (863 Program)

Contract grant number: 2009AA06Z407

Published online 2 September 2011 in Wiley Online Library (wileyonlinelibrary.com). DOI 10.1002/tox.20751
}

ization as well as in numerous other applications (Key et al., 1997; Prevedouros et al., 2006). The corresponding environmental consequences due to the wide usage of this kind of compounds should be thoroughly investigated. Indeed, the persistence, bioaccumulation, and biomagnification of PFCs have drawn much attention in environmental research field. PFCs were detected in wildlife, human blood, and other environmental matrices, wherein the dominant chemicals are perfluorosulfonates (PFSAs) and perfluorocarboxylates (PFCAs) (Giesy and Kannan, 2002; Taniyasu et al., 2003; Van de Vijver et al., 2003; Kannan et al., 2004). In recent years, fluorotelomer alcohols (FTOHs), a class of volatile chemicals with the capability of undergoing long-range atmospheric transport, have aroused public interest; their production is estimated to be $12 \times 10^{6} \mathrm{~kg}$ per year (DuPont, 2005). These FTOHs are regarded as the potential precursors that may form PFCAs and other related compounds through biodegradation and atmospheric oxidation (Ellis et al., 2004; Hurley et al., 2004; Wallington et al., 2006; Nilsson et al., 2010). Besides occurrence in the troposphere (Martin et al., 2002; Stock 
et al., 2004), these compounds were also detected in the rainwater, surface water, and waste water treatment plant effluents (Mahmoud et al., 2009).

During the past several years, some of the PFCs have been shown to possess undesirable endocrine disrupting effects both in vitro and in vivo.

Perfluorooctane sulfonate (PFOS), perfluorooctane acid (PFOA), and FTOHs could induce vitellogenin (VTG) in primary cultured tilapia hepatocytes through estrogen receptor pathway, while the combination of PFCs and E2 caused anti-estrogenic effect (Liu et al., 2007). Upregulation of the estrogen receptor occurred in MCF-7 breast cancer cells as a consequence of exposures to $1 \mathrm{H}, 1 \mathrm{H}, 2 \mathrm{H}, 2 \mathrm{H}$ perfluorooctan-1-ol (6:2 FTOH)or $1 \mathrm{H}, 1 \mathrm{H}, 2 \mathrm{H}, 2 \mathrm{H}$-perfluoro-decan-1-ol (8:2 FTOH) (Maras et al., 2006). Treatments with 6:2 FTOH, 8:2 FTOH and 2,2,3,3,4,4,5,5,6,6, $7,7,8,8,9,9,10,10,10$-nonadecafluoro-1-decanol (NFDH) dose-dependently induced hER-mediated transcriptional activity with interaction between the hERa or hERb ligand binding domain and TIF2 (Ishibashi et al., 2007). A number of in vivo studies also revealed the properties of endocrine disruption of these PFCs. PFOS reduced serum thyroxine (T4) and triiodothyronine (T3) in rats and mice (Thibodeaux et al., 2003) resulting the delay of the development. In male rats, exposure to PFOA decreased testosterone levels in serum and testicular interstitial fluid, increased serum estradiol levels and testis lesions (Biegel et al., 1995). Rats exposed to PFOA by oral gavage also significantly downregulated 3-hydroxy-3-methylglutaryl-Coenzyme A (HMG$\mathrm{CoA}$ ) reductase mRNA, the rate-limiting enzyme in cholesterol biosynthesis (Guruge et al., 2006). Perfluorododecanoic acid (PFDoA) exposure resulted in significant declines in mRNA expression of several genes involved in cholesterol transport and steroid biosynthesis, while the gene expression of luteinizing hormone receptor and aromatase

\section{Abbreviations}

\begin{tabular}{|c|c|}
\hline ANOVA & analysis of variance \\
\hline APFO & ammonium perfluorooctanoate \\
\hline ECF & electrochemical fluorination \\
\hline $\mathrm{EE}$ & ethinylestradiol \\
\hline ELISA & enzyme-linked immunosorbent assay \\
\hline ER & estrogenic receptor \\
\hline ERE & estrogen-responsive element \\
\hline FIA & perfluorinated iodine alkane \\
\hline FTOH & fluorotelomer alcohol \\
\hline GSI & gonadal-somatic index \\
\hline HMG & 3-hydroxy-3-methylglutaryl \\
\hline HPG & hypothalamic-pituitary-gonadal \\
\hline HPT & hypothalamic-pituitary-thyroid \\
\hline HRP & horseradish peroxidase \\
\hline HSI & hepatic-somatic index \\
\hline NSB & nonspecific binding \\
\hline PFC & polyfluorinated compound \\
\hline PFCA & perfluorocarboxylate \\
\hline PFDoA & perfluorododecanoic acid \\
\hline PFOI & perfluorooctyl iodide \\
\hline PFSA & perfluorosulfonate \\
\hline TH & thyroid hormone \\
\hline TMB & tetrabenzidine \\
\hline VTG & vitellogenin \\
\hline
\end{tabular}

was not significantly changed (Shi et al., 2007). As the increasing detections of PFCs in aquatic species, more and more studies were carried out to investigate the endocrine effects of PFCs in typical aquatic organisms such as fish. PFCs could also cause endocrine disruption in oviparous fish species. PFOS modulated the expression levels of certain genes in the hypothalamic-pituitary-thyroid (HPT) axis and led to changes in thyroid hormone (TH) levels in zebrafish larvae which could directly reflect disrupted TH status (Shi et al., 2009). PFOS exposure could also inhibit VTG mRNA expression after first 2 weeks, but upregulate the expression later in ovoviparous swordtail fish juveniles (Han and Fang, 2010). PFOA disrupted the activity of estrogen by inducing hepatic estrogen-responsive genes in male rare minnow (Wei et al., 2007). In addition, 6:2 FTOH and 8:2 FTOH induced hepatic VTG through activation of estrogenic receptor $\alpha(\mathrm{ER} \alpha)$ in male medaka (Ishibashi et al., 2008). Further study showed that waterborne exposure of 6:2 FTOH could alter plasma levels of $\mathrm{T}$ and $\mathrm{E} 2$, and gene expression profile of hypothalamic-pituitarygonadal (HPG) axis in zebrafish (Liu et al., 2009). Regarded as the potential precursor of PFCAs, FTOH showed higher estrogenic effects compared with the other chemical forms. Similarly, fluorotelomer acids, as the intermediates in the degradation of FTOHs to PFCAs, were testified to be more toxic than perfluorinated acids to aquatic organisms (Phillips et al., 2007). Compared with the other PFCs, there were few reports on the toxicological effects of the precursors of PFCs, especially for some new precursors that have been reported recently such as perfluorinated iodine alkanes (FIAs).

FIAs, as a kind of chemicals containing the fully fluorinated alkyl chain with an iodine atom at one end, are important intermediates in the industrial synthesis of FTOHs, ammonium perfluorooctanoate (APFO), and related compounds using telomerization (Lehmler, 2005). As the telomerization gradually replaced electrochemical fluorination (ECF) process in the production of several PFCs, the demand and production of FIAs are increasing. Therefore, the risk of their release into environment also increases. The presence of four FIAs in the air around a fluorochemical manufacturing plant was confirmed (Ruan et al., 2010 a,b. Among the detected four compounds, perfluorooctyl iodide (PFOI) has the highest commercial value due to the wide usage in its derivatives. Unfortunately, the toxicology of this kind of chemical has not been characterized.

Although there are a lot of studies focusing on the endocrine disruption potential of PFCs, little attention was paid to PFOI or other FIAs. In this study, we assessed the estrogenic effects of PFOI by the determination of the expression levels of estrogen-responsive genes such as ERs (ER $\alpha$ and $\operatorname{ER} \beta$ ) and the VTGs (VTG I and VTG II). The induction of the typical biomarker for estrogenic response, VTG in the livers of adult male medaka was also analyzed. It 
was the first in vivo rudimentary study to evaluate the estrogenic effects of PFOI.

\section{MATERIALS AND METHODS}

\section{Reagents}

PFOI (purity: 99\%) from Acros Organics (Geel, Belgium) was dissolved in ethanol and stored as a stock solution $(15000 \mathrm{mg} / \mathrm{l})$ at $4{ }^{\circ} \mathrm{C}$. The TRIzol ${ }^{\circledR}$ reagent and oligo-(dT) 18 primers were purchased from Invitrogen (New Jersey, NJ). SYBR $^{\circledR}$ Green PCR kit and M-MLV transcriptase were obtained from Promega (Madison, WI). E2 (purity: 99\%), the positive control was obtained from Alfa. Medaka vitellogenin ELISA Kit was purchased from Cayman Chemical Company (Ann Arbor, MI). All other chemicals used in this study were of analytical grade.

\section{Animals}

The fish model, medaka with mean values of $0.34 \mathrm{~g}$ in weight (about 16 weeks) was obtained from a stable colony maintained in glass tanks in our laboratory. The condition of maintenance has been previously reported ( $\mathrm{Li}$ et al., 2008). The fish were fed twice a day with artemia and kept under a 12-h light and 12-h dark circle in the 3-L glass tanks and the water or exposure solution was completely changed every day. In this study, a series of exposure concentrations of PFOI including 0, 0.05, 0.5, $5 \mathrm{mg} / \mathrm{L}$ is tested. For gene expression analysis of $\operatorname{ER} \alpha, \operatorname{ER} \beta$, VTG I, and VTG II, adult male medaka were exposed to a series of concentrations of PFOI and $5 \mu \mathrm{g} / \mathrm{L}$ E2 for $12 \mathrm{~h}$ and $72 \mathrm{~h}$, respectively. Three fish were set in each group. For the analysis of hepatic VTG synthesis, medaka was exposed to a series of concentrations of PFOI and $5 \mu \mathrm{g} / \mathrm{L}$ E2 for 3, 7, and 14 days, respectively. Three fish were set in each group. A control group exposed to the carrier solvent $(0.05 \%$ ethanol) was set for each experiment.

\section{Total RNA Isolation and Reverse-Transcription PCR}

A single step acid guanidinium thiocyanate-phenol-chloroform extraction method was applied to extract total RNA from liver tissue of male medaka using TRIzol ${ }^{\circledR}$ reagent according to the manufacture's specifications. The concentration of total RNA was quantified by the absorbance at $260 \mathrm{~nm}$ using a NanoDrop 2000 Micro-Volume UV-Vis Spectrophotometer (Thermo Scientific). The purity of total RNA was assessed by determining the A260/A280 ratio. First-strand cDNA synthesis was performed using M-MLV transcriptase and oligo-(dT) 18 primers. Briefly, a $2-\mu \mathrm{g}$ aliquot of total RNA was combined with $1 \mu \mathrm{L}$ of $0.5 \mu \mathrm{g} / \mu \mathrm{L}$ of oligo-(dT)18, and RNase-free water to a final volume of $15 \mu \mathrm{L}$. Mixtures were denatured at $70^{\circ} \mathrm{C}$ for $5 \mathrm{~min}$ and then quickly chilled on ice for $2 \mathrm{~min}$. After cooling, $5 \mu \mathrm{L} 5 \times \mathrm{M}$ MLV reaction buffer, $1.5 \mu \mathrm{L}$ of deoxynucleotide triphosphates (dNTP; $2 \mathrm{mM}$ each), $0.5 \mu \mathrm{L}$ of RNase inhibitor(25 $\mathrm{U}), 2 \mu \mathrm{L}$ of RNase free water, and $1 \mu \mathrm{L}$ of M-MLV transcriptase $(200 \mathrm{U})$ were added to a final volume of $25 \mu \mathrm{L}$. The reaction mixture was incubated for $60 \mathrm{~min}$ at $42^{\circ} \mathrm{C}$, then heated to $87^{\circ} \mathrm{C}$ for $10 \mathrm{~min}$ to stop the reaction. The cDNA was stored at $-20^{\circ} \mathrm{C}$ until further analysis.

\section{Real-Time PCR Reaction}

Real-time Q-RT-PCR was performed using Mx3000PTM Real-Time PCR instrument (Stratagene, La Jolla, CA) by using SYBR ${ }^{\circledR}$ Green PCR kit. The reaction $(25 \mu \mathrm{L})$ contained $10 \mu \mathrm{L}$ of SYBR ${ }^{\circledR}$ Green PCR master mix, $2 \mu \mathrm{L}$ of diluted cDNA template, $4 \mu \mathrm{L}$ of nuclease-free water, and 4 $\mu \mathrm{L}$ of target-specific primer( $1 \mu \mathrm{M}$ each). The specific primers for ERs, VTGs, and $\beta$-actin sequences were used as previously reported (Ishibashi et al., 2008). The reaction mixture was denatured at $95^{\circ} \mathrm{C}$ for $3 \mathrm{~min}$ before the first PCR cycle. The thermal cycle was denaturation at $95^{\circ} \mathrm{C}$ for $30 \mathrm{~s}$; annealing at $57^{\circ} \mathrm{C}$ for $30 \mathrm{~s}$; and extension at $72^{\circ} \mathrm{C}$ for $30 \mathrm{~s}$. After 40 cycles, the reaction mixture was incubated at $72^{\circ} \mathrm{C}$ for $30 \mathrm{~s}$, then a melting curve analysis was carried out to demonstrate the specificity of the PCR product as displayed by a single peak. The gene expression level was normalized using the expression level of $\beta$-action mRNA. All experiments were repeated three times for each sample.

\section{Measurement of Hepatic VTG}

An enzyme-linked immunosorbent assay (ELISA) was used to measure hepatic VTG protein level in medaka. The fish were cold shocked in the mixture of ice and water for 1-2 min, and the liver was sectioned, weighed, and homogenized in $1000 \mu \mathrm{L}$ of ice-cold assay buffer in the ELISA kit. The homogenized samples were centrifuged $(8000 \times g, 10$ $\min , 4^{\circ} \mathrm{C}$ ), and the supernatant was collected and stored at $-80^{\circ} \mathrm{C}$ until further analysis, conducted within 1 week according to the manufacture's protocol. Medaka VTG protein standard was thawed on ice, dissolved, and serially diluted. Three different dilutions of each sample were prepared. $100 \mu \mathrm{L}$ dilution buffer was added to each of the two nonspecific binding (NSB) wells. Medaka VTG samples and standards $(100 \mu \mathrm{L})$ were added to the remaining wells. Plates were sealed and incubated at $25^{\circ} \mathrm{C}$ for $1 \mathrm{~h}$. Subsequently, plates were washed three times, with $300 \mu \mathrm{L}$ of washing buffer per well. Then $100 \mu \mathrm{L}$ of the diluted detecting antibody, labeled with enzyme horseradish peroxidase (HRP), were added to each well. The plates were sealed and incubated at $25^{\circ} \mathrm{C}$ for $1 \mathrm{~h}$. The wells were washed with $300 \mu \mathrm{L}$ of washing buffer five times. One hundred microliters of tetrabenzidine (TMB) substrate solution was added to each well. Plates were incubated in the dark (covered with aluminum foil) at room temperature for $15 \mathrm{~min}$. 
Subsequently, $100 \mu \mathrm{L}$ of $0.3 \mathrm{M} \mathrm{H}_{2} \mathrm{SO}_{4}$ was added to each well to stop the reaction. Five minutes later, the absorbance was determined at $450 \mathrm{~nm}$ by a Multimode Microplate Spectrophotometer (Thermo Scientific). Concentrations of VTG in liver samples were calculated according to the methods provided by the manufacturer of the ELISA kit.

\section{Statistical Analysis}

Gene expression experiments were performed three times to confirm the results, and the data were expressed as means \pm SEM from one representative experiment. All data were analyzed for significant differences $(P<0.05)$ using oneway analyzed of variance (ANOVA). All data were analyzed using SPSS Software (version 16.0).

\section{RESULTS}

\section{Fish Physiological Condition}

There were no mortalities in any of the treatment groups during the exposure period. No obvious gonadal-somatic index (GSI) changed in medaka exposed to $0.05 \mathrm{mg} / \mathrm{L}$ or $0.5 \mathrm{mg} / \mathrm{L}$ PFOI [Fig. 1(A)]. While for those exposed to 5 $\mathrm{mg} / \mathrm{L}$ PFOI for 14 days, the GSI values significantly decreased when compared with the control group $[P<$ 0.05; Fig. 1(A)]. The mean GSI value of the control group was 0.73 , while the mean GSI values of the $5 \mathrm{mg} / \mathrm{L}$ treatment group decreased to 0.60 . The hepatic-somatic index (HSI) values of the fish in $5 \mathrm{mg} / \mathrm{L}$ of PFOI group significantly increased after 7 and 14 days of exposure [Fig. 1(B)]. After 7 days of exposure to $5 \mathrm{mg} / \mathrm{L}$, the HSI value of fish was increased from 2.37 to 3.25 . And after 14 days of exposure to $5 \mathrm{mg} / \mathrm{L}$, the HSI value of fish was increased from 2.26 to 3.28 . For the HSI value of medaka exposed to $0.5 \mathrm{mg} / \mathrm{L}$, it obviously increased after 14 days' exposure. The mean HSI value increased from 2.26 to 3.28. While for those after 3 days of exposure, no changes were observed in their HSI values [Fig. 1(B)].

\section{Estrogen-Related Genes Assay}

The potential estrogenic activities of PFOI evaluated by monitoring changes in the expression of estrogen related genes $\operatorname{ER} \alpha$, ER $\beta$, VTG I, and VTG II in the livers from medaka exposed to PFOI for $12 \mathrm{~h}$ and $72 \mathrm{~h}$, using RT-PCR techniques. According to Figure 2, significant upregulation of ER $\propto$ (2.8-, 32.7-, and 89.4-fold) were observed in fish exposed to a series of concentrations of PFOI for $72 \mathrm{~h}$ and compared with the control groups, respectively [Fig. 2(A)]. While there were no statistically significant differences in the $0.05 \mathrm{mg} / \mathrm{L}$ and $0.5 \mathrm{mg} / \mathrm{L}$ exposure groups compared with the control group after $12 \mathrm{~h}$ exposure, but in $5 \mu \mathrm{g} / \mathrm{L} \mathrm{E} 2$ treated group, the expression of ER $\alpha$ was significantly increased by 123.7 folds. As for $\operatorname{ER~} \beta$, no significant
(A)

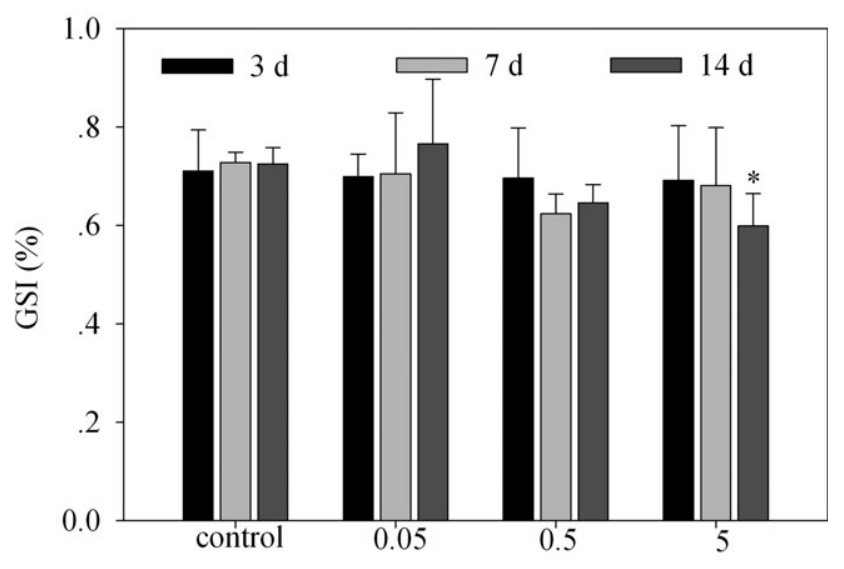

(B)

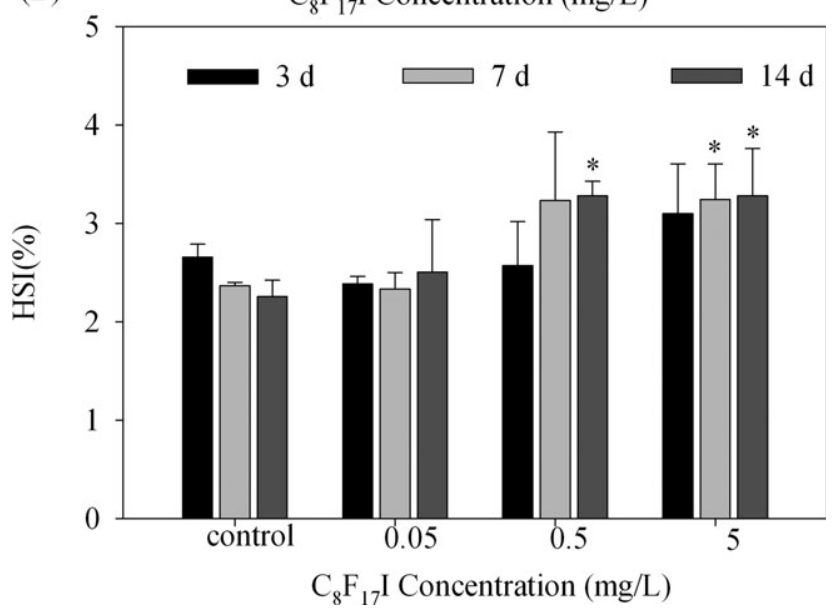

Fig. 1. $\mathrm{GSI}(\mathrm{A}), \mathrm{HSI}(\mathrm{B})$ Alterations in male medaka exposed to $0,0.05,0.5,5 \mathrm{mg} / \mathrm{L}$ PFOI for $3 \mathrm{~d}, 7 \mathrm{~d}$, and $14 \mathrm{~d}$. The results are mean \pm SEM of three individual fish. ${ }^{\star} P<0.05$ indicates significant difference compared with the corresponding control.

changes were observed in $12 \mathrm{~h}$ exposure groups at all PFOI exposure levels and E2 treated group. While for $72 \mathrm{~h}$ exposure, the expression of ER $\beta$ was significantly upregulated in $0.5 \mathrm{mg} / \mathrm{L}$ and $5 \mathrm{mg} / \mathrm{L}$ exposure groups (9.6- and 15.8fold), relative to the control, [Fig. 2(B)]. PFOI and E2 exposure also induced obvious expression of both VTG I and VTG II in all groups. After exposure to a series of concentrations of PFOI and $5 \mu \mathrm{g} / \mathrm{L} \mathrm{E} 2$ for $12 \mathrm{~h}$, the expression of VTG I were increased by 4.1-, 7.0-, 7.9-, and 787.3-folds, respectively, and the expression of VTG II were increased by 1.7-, 1.9-, 4.2-, and 261.8-folds, respectively [Fig. 2(C,D)].

\section{Hepatic VTG Protein Induction}

To assess the estrogenic effects of PFOI on medaka for different exposure time, the induction of hepatic VTG protein was investigated in the fish exposed to a series of concentrations of PFOI for 3, 7, and 14 days, respectively. Hepatic 
(A)

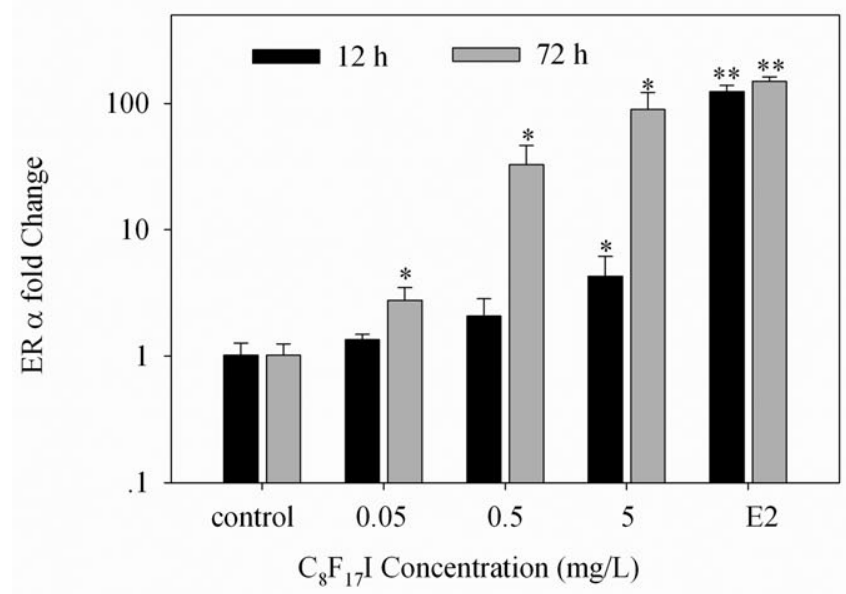

(C)

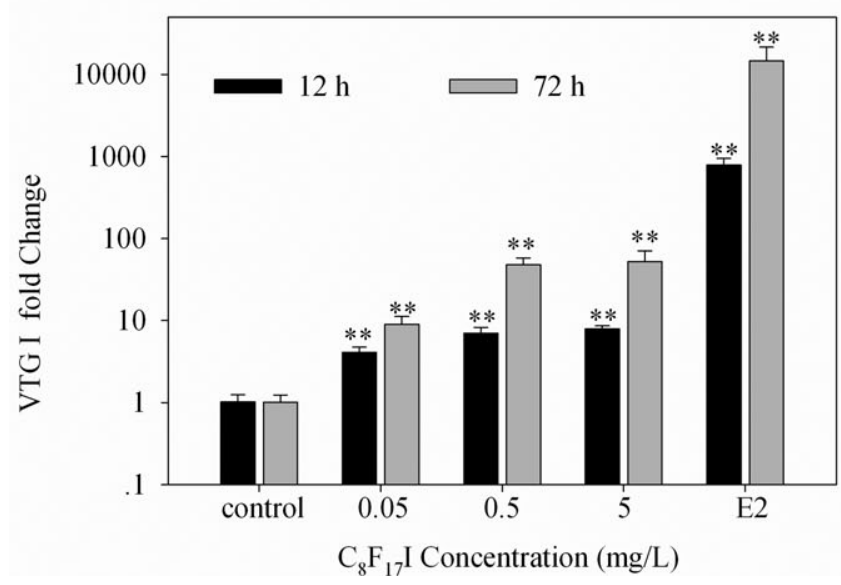

(B)

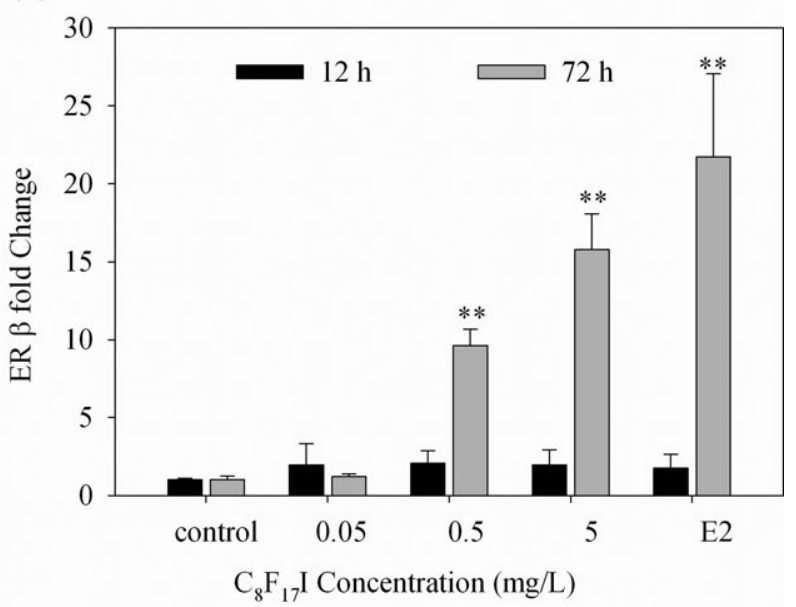

(D)

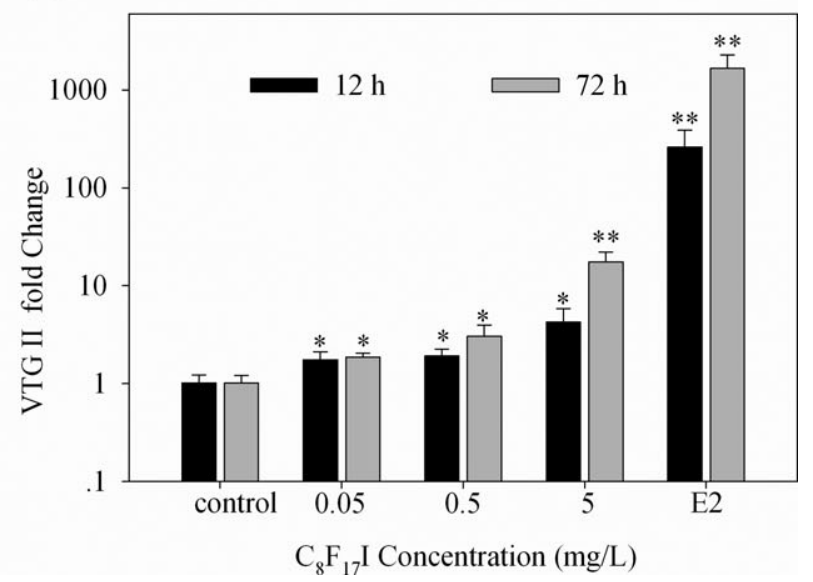

Fig. 2. Gene expression of ER $\alpha(\mathrm{A}), \mathrm{ER} \beta(\mathrm{B}), \mathrm{VTG} I(\mathrm{C})$, and VTG II (D) in the liver of male medaka exposed to $0,0.05,0.5,5 \mathrm{mg} / \mathrm{L}$ of PFOI and $5 \mu \mathrm{g} / \mathrm{L}$ E2 for $12 \mathrm{~h}$ and $72 \mathrm{~h}$. The results are mean \pm SEM of three individual fish. ${ }^{\star} P<0.05$ and ${ }^{\star \star} P<0.01$ indicate significant difference compared with the corresponding control.

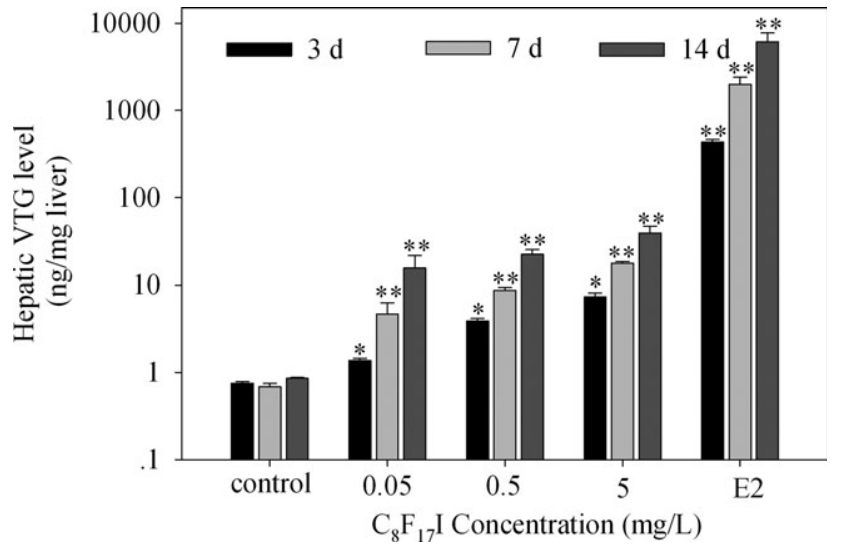

Fig. 3. Concentrations of hepatic VTG protein in male medaka exposed to $0,0.05,0.5,5 \mathrm{mg} / \mathrm{L}$ of PFOI and $5 \mu \mathrm{g} / \mathrm{L}$ E2 for $3 \mathrm{~d}, 7 \mathrm{~d}$, and $14 \mathrm{~d}$. The results are mean \pm SEM of three individual fish. ${ }^{\star} P<0.05$ and ${ }^{\star \star} P<0.01$ indicate significant difference compared with the corresponding control.
VTG protein concentrations of all the exposure groups were significantly higher than their corresponding control groups. Among the treatment groups of 3 days of exposure, the VTG protein levels increased from $1.4 \mathrm{ng} / \mathrm{mg}$ liver $(0.05 \mathrm{mg} / \mathrm{L})$ to $7.4 \mathrm{ng} / \mathrm{mg}$ liver $(5 \mathrm{mg} / \mathrm{L})$. After the fish exposed to $0.5 \mathrm{mg} / \mathrm{L}$ for 3 days, the VTG protein level was $3.9 \mathrm{ng} / \mathrm{mg}$ liver, while the VTG protein level was increased to $22.4 \mathrm{ng} / \mathrm{mg}$ after 14 days of exposure (Fig. 3). The hepatic VTG protein is induced in a dose- and time-dependent manner. VTG protein level of induction in fish exposed to E2 was much higher than VTG protein level found in the liver of fish treated with PFOI.

\section{DISCUSSION}

The estrogen-like activities of the PFOI is studied using the fish model of medaka in this study. To our knowledge, it is the first report on the estrogenic potential of PFOI in vivo. 
This study demonstrates that PFOI causes significant upregulation of estrogenic responsive genes like ERs and VTGs in the liver of adult male medaka. Likewise, the synthesis of hepatic VTG protein is also detected. This study provided important information on the endocrine disrupting effects of PFOI, offering a tool for the evaluation of toxicities of PFCs using medaka fish model, which helps to discover the potential toxicities and underlying mechanisms of new PFCs.

During this study, the estrogenic effects of PFOI were characterized by the combinations of estrogenic-related endpoints. First, the changes of important estrogenic responsible genes such as ERs, VTGs after short time exposure were accessed using RT-PCR. Three ERs, $(\mathrm{ER} \alpha, \mathrm{ER} \beta$, $\mathrm{ER} \gamma$ ) have been identified in teleosts (Hawkins et al., 2000). Abnormal induction of ERs in male or immature fish may have adverse consequences. In different fish species, the different ERs do not equally contribute to gene transcription of VTG. In most cases, estrogen-like chemicals can bind to their specific ERs, acting as ligand-activated transcription factors to promote estrogen target gene expression and then the corresponding VTG protein was synthesized. In some species, ER $\alpha$ plays an important role in regulating the level of VTG (Menuet et al., 2004; SaboAttwood et al., 2004; Andreassen et al., 2005). And it is known that ER $\alpha$ is auto-regulated by the presence of estrogen-responsive elements (EREs) in the promoter region of $\mathrm{ER} \alpha$ in rainbow trout (Le Drean et al., 1995). Some in vivo and in vitro tests suggest that the estrogenic effect of FTOH is mediated in ER $\alpha$ signaling way. Eight hours' exposure of $10 \mu \mathrm{M}$ 6:2 FTOH to male medaka induced expression of ER $\alpha\urcorner 10$ folds compared with the control group, whereas no significant induction was observed in ER $\beta$, VTG I, and VTG II expression (Ishibashi et al., 2008). This study shows ER $\alpha$ is 4.3 folds upregulated in fish exposed to 5 $\mathrm{mg} / \mathrm{L}(9 \mu \mathrm{M})$ PFOI for $12 \mathrm{~h}$. The mRNA levels of VTG I and VTG II are also significantly increased by 7.9 folds and 4.2 folds, respectively, compared with controls. The result from the positive control of E2 showed that it obviously increased mRNA levels of VTG I and VTG II in exposed fish, confirming the feasibility of the medaka model for endocrine disruptor study, although PFOI showed comparatively less strong effects on both the VTG I and VTG II transcripts after 12 and $72 \mathrm{~h}$ ' exposure. No change is observed in ER $\beta$ after $12 \mathrm{~h}$ exposure. After $72 \mathrm{~h}$, the ER $\beta$ is then upregulated, but the upregulation of ER $\beta$ is much lower than that of ER $\alpha$. The difference suggests that PFOI induces both VTG I and VTG II mRNAs in a comprehensive way. There are other possible pathways for PFOI regulation in medaka besides ER $\alpha$ signaling way.

The levels of VTG protein in liver are also measured. VTG protein, the precursor of egg yolk protein phosvitin and lipovitelline expressed in the females of nearly all oviparous species, is synthesized in the liver, then transported through the blood to growing oocytes and accumulate in yolky eggs as a food reserve for embryos and early larval stages (Tyler et al., 1988). The synthesis of VTG is recognized as a hormone-dependent pathway. Estrogens interact with ERs, and then lead to VTG gene induction, transcription and the synthesis of VTG protein in liver (Lazier et al., 1985). VTG has been regarded as a highly specific biomarker for screening estrogenic effects of xeno-compounds in fish (Sumpter and Jobling, 1995). Several studies have reported that PFCs can induce the anomalous production of VTG in males. Hepatic VTG protein levels in male rare minnows exposed to $10 \mathrm{mg} / \mathrm{L}$ of PFOA for 14 days were increased 20 times higher compared with the controls (Wei et al., 2007). Rare minnow is more sensitive than medaka in the evaluation of estrogen compounds, for example, a study indicated that the sensitivity of Chinese rare minnow to 17- $\alpha$-ethinylestradiol $\left(\mathrm{EE}_{2}\right)$, is about 10-fold higher than that of Japanese medaka based on VTG induction (Ma et al., 2007). Our study showed that hepatic VTG protein levels in male medaka exposed to $5 \mathrm{mg} / \mathrm{L}$ of PFOI for 14 days were increased almost 46 times higher compared with the controls. The hepatic VTG protein levels in male medaka exposed to $5 \mu \mathrm{g} / \mathrm{L}$ E2 for 14 days were increased 7156 times higher compared with the controls. Our study revealed marked elevation in hepatic VTG protein concentrations in adult male medaka exposed to PFOI after 3 days when compared with the control group, with the lowestobserved-effect concentration (LOEC) estimated to be less than $0.05 \mathrm{mg} / \mathrm{L}(0.1 \mu \mathrm{M})$. 6:2 FTOH induced the increase of VTG protein in liver of male medaka after 3 days, with the LOEC estimated to be $1 \mu \mathrm{M}$ (Ishibashi et al., 2008).

Estrogenic chemicals may result in pathological abnormalities. Previous studies indicated that 4-nonylphenol caused an increase of HSI and a decrease of GSI (Kang et al., 2003). The increases of HSI in a dose-dependent manner and the decreases of GSI are also observed in this study. These findings indicate that PFOI exposure may disrupt the endocrine system of the fish, thus leading to the final pathological alterations.

This study demonstrates that PFOI induce the expression of ERs, VTGs, and hepatic VTG protein synthesis, but the underlying mechanism and the toxicological consequences remain unclear. No information is currently available on the estrogenic effects of other kinds of FIAs or the combinations of different FIAs. Furthermore, the level of PFOI in aquatic environment hasn't been reported although previous reports verified the presence of four FIAs in the troposphere (Ruan et al., 2010a,b. Future work is necessary for the long-term and low dose effects of PFOI on fish reproduction.

\section{REFERENCES}

Andreassen TK, Skjoedt K, Korsgaard B. 2005. Upregulation of estrogen receptor alpha and vitellogenin in eelpout (Zoarces 
viviparus) by waterborne exposure to 4-tert-octylphenol and 17 beta-estradiol. Comp Biochem Physiol C 140:340-346.

Biegel LB, Liu RC, Hurtt ME, Cook JC. 1995. Effects of ammonium perfluorooctan-oate on Leydig cell function: In vitro, in vivo, and ex vivo studies. Toxicol Appl Pharmacol 134:18-25.

DuPont Company. 2005. Dupont Global PFOA Strategy Update: Presentation to USEPA OPPT. Public Docket AR226-1914, USEPA Office of Pollution Prevention and Toxics. Washington, DC.

Ellis DA, Martin JW, De Silva AO, Mabury SA, Hurley MD, Sulbaek Andersen MP, Wallington TJ. 2004. Degradation of fluorotelomer alcohols: A likely atmospheric source of perfluorinated carboxylic acids. Environ Sci Technol 38:3316-3321.

Giesy JP, Kannan K. 2001. Global distribution of perfluorooctane sulfonate in wildlife environment. Environ Sci Technol 35: 1339-1342.

Guruge KS, Yeung LW, Yamanaka N, Miyazaki S, Lam PK, Giesy JP, Jones PD, Yamashita N. 2006. Gene expression profiles in rat liver treated with perfluorooctanoic acid (PFOA). Toxicol Sci 89:93-107.

Han J, Fang ZQ. 2010. Estrogenic effects, reproductive impairment and developmental toxicity in ovoviparous swordtail fish (Xiphophorus helleri) exposed to perfluorooctane sulfonate (PFOS). Aquat Toxicol 99:281-290.

Hawkins MB, Thornton JW, Crews D, Skipper JK, Dotte A, Thomas P. 2000. Identification of a third distinct estrogen receptor and reclassification of estrogen receptors in teleosts. Proc Natl Acad Sci 97:10751-10756.

Hurley MD, Ball JC, Wallington TJ, Sulbaek Andersen MP, Ellis DA, Martin JW, Mabury SA. 2004. Atmospheric chemistry of 4:2 fluorotelomer alcohol $\left(\mathrm{CF}_{3}\left(\mathrm{CF}_{2}\right)_{3} \mathrm{CH}_{2} \mathrm{CH}_{2} \mathrm{OH}\right)$ : Products and mechanism of $\mathrm{Cl}$ atom initiated oxidation. J Phys Chem A 108:5635-5642.

Ishibashi $\mathrm{H}$, Ishida $\mathrm{H}$, Matsuoka $\mathrm{M}$, Tominaga $\mathrm{N}$, Arizono $\mathrm{K}$. 2007. Estrogenic effects of fluorotelomer alcohols for human estrogen receptor isoforms $\alpha$ and $\beta$ in vitro. Biol Pharm Bull 30:1358-1359.

Ishibashi H, Yamauchi R, Matsuoka M, Kim JW, Hirano M, Yamaguchi A, Tominaga N, Arizono K. 2008. Fluorotelomer alcohols induce hepatic vitellogenin through activation of the estrogen receptor in male medaka (Oryzias latipes). Chemosphere 71:1853-1859.

Kang IJ, Yokota H, Oshima Y, Tsuruda Y, Hano T, Maeda M, Imada N, Tadokoro H, Honjo T. 2003. Effects of 4-nonylphenol on reproduction of Japanese medaka Oryzias latipes. Environ Toxicol Chem 22:2438-2445.

Kannan K, Corsolini S, Falandysz J, Fillmann G, Kumar KS, Loganathan BG, Mohd MA, Olivero J, Van Wouwe N, Yang JH, Aldoust KM. 2004. Perfluorooctanesulfonate and related fluorochemicals in human blood from several countries. Environ Sci Technol 38:4489-4495.

Key BD, Howell RD, Criddle CS. 1997. Fluorinated organics in the biosphere. Environ Sci Technol 31:2445-2454.

Lazier CB, Lonergan K, Mommsen TP. 1985. Hepatic estrogen receptors and plasma estrogen-binding activity in the Atalantic salmon. Gen Comp Endocrinol 57:234-245.

Le Drean Y, Lazennec G, Kern L, Saligaut D, Pakdel F, Valotaire Y. 1995. Characterization of an estrogen-responsive element implicated in regulation of the rainbow trout estrogen receptor gene. J Mol Endocrinol 15:37-47.

Lehmler H. 2005. Synthesis of environmentally relevant fluorinated surfactantssa review. Chemosphere 58:1471-1496.

Li HC, Zhang JS, Wang T, Luo WR, Zhou QF, Jiang GB. 2008. Elemental selenium particles at nano-size (Nano-Se) are more toxic to medaka (Oryzias latipes) as a consequence of hyperaccumulation of selenium: A comparison with sodium selenite. Aquat Toxicol 89:251-256.

Liu CS, Du YB, Zhou BS. 2007. Evaluation of estrogenic activities and mechanism of action of perfluorinated chemicals determined by vitellogenin induction in primary cultured tilapia hepatocytes. Aquat Toxicol 85:267-277.

Liu CS, Yu LQ, Deng J, Lam PK, Wu RS, Zhou BS. 2009. Waterborne exposure to fluorotelomer alcohol 6:2 FTOH alters plasma sex hormone and gene transcription in the hypothalamic-pituitary-gonadal (HPG) axis of zebrafish. Aquat Toxicol 93:131-137.

Ma TW, Wang ZJ, Gong SJ. 2007. Comparative sensitivity in Chinese rare minnow (Gobiocypris rarus) and Japanese Medaka (Oryzias latipes) exposed to ethinylestradiol. J Environ Sci Health A Tox Hazard Subst Environ Eng 42:889-894.

Mahmoud MA, Kärrman A, Oono S, Harada KH, Koizumi A. 2009. Polyfluorinated telomers in precipitation and surface water in an urban area of Japan. Chemosphere 47:467-472.

Maras M, Vanparys C, Muylle F, Robbens J, Berger U, Barber JL, Blust R, De Coen W. 2006. Estrogen-like properties of fluorotelomer alcohols as revealed by MCF-7 breast cancer cell proliferation. Environ Health Perspect 114:100-105.

Martin JW, Muir DC, Moody CA, Ellis DA, Kwan WC, Solomon KR, Mabury SA. 2002. Collection of airborne fluorinated organics and analysis by gas chromatography/chemical ionization mass spectrometry. Anal Chem 74:584-590.

Menuet A, Le Page Y, Torres O, Kern L, Kah O, Pakdel F. 2004. Analysis of the estrogen regulation of the zebrafish estrogen receptor (ER) reveals distinct effects of ER alpha, ER beta 1 and ER beta 2. J Mol Endocrinol 32:975-986.

Nilsson H, Kärrman A, Rotander A, van Bavel B, Lindström G, Westberg H. 2010. Inhalation exposure to fluorotelomer alcohols yield perfluorocarboxylates in human blood? Environ Sci Technol 44:7717-7722.

Phillips MM, Dinglasan-Panlilio MJA, Mabury SA, Solomon KR, Sibley PK. 2007. Fluorotelomer acids are more toxic than perfluorinated acids. Environ Sci Technol 41:7159-7563.

Prevedouros K, Cousins IT, Buck RC, Korzeniowski SH. 2006. Sources, Fate and Transport of Perfluorocarboxylates. Environ Sci Technol 40:32-44.

Ruan T, Wang YW, Zhang QH, Ding L, Wang P, Qu GB, Wang C, Wang T, Jiang GB. 2010a. Trace determination of airborne polyfluorinated iodine alkanes using multisorbent thermal desorption/gas chromatography/high resolution mass spectrometry. J Chromatogr A 1217:4439-4447.

Ruan T, Wang YW, Wang T, Zhang QH, Ding L, Liu JJ, Wang C, Qu GB, Jiang GB. 2010b. Presence and partitioning behavior of polyfluorinated iodine alkanes in environmental matrices around a fluorochemical manufacturing plant: Another possible source for perfluorinated carboxylic acids? Environ Sci Technol 44:5755-5761. 
Sabo-Attwood T, Kroll KJ, Denslow ND. 2004. Differential expression of largemouth bass (Micropterus salmoides) estrogen receptor isotypes alpha, beta, and gamma by estradiol. Mol Cell Endocrinol 218:107-118.

Shi XJ, Liu CS, Wu GQ, Zhou BS. 2009. Waterborne exposure to PFOS causes disruption of the hypothalamus-pituitary-thyroid axis in zebrafish larvae. Chemosphere 77:1010-1018.

Shi ZM, Zhang HX, Liu Y, Xu MQ, Dai JY. 2007. Alterations in gene expression and testosterone synthesis in the testes of male rats exposed to perfluorododecanoic acid. Toxicol Sci 98:206215.

Stock NL, Lau FK, Ellis DA, Martin JW, Muir DC, Mabury SA. 2004. Polyfluorinated telomer alcoholsandsulfonamides in the North American troposphere. Environ Sci Technol 38:991-996.

Sumpter JP, Jobling S. 1995. Vitellogenesis as a biomarker for estrogenic contamination of the aquatic environment. Environ Health Perspect 103:173-178.

Taniyasu S, Kannan K, Horii Y, Hanari N, Yamashita N. 2003. A survey of perfluoroctanesulfonate and related perfluorinated organic compounds in water, fish, birds, and humans from Japan. Environ Sci Technol 37:2634-2639.
Thibodeaux JR, Hanson RG, Rogers JM, Grey BE, Barbee BD, Richards JH, Butenhoff JL, Stevenson LA, Lau C. 2003. Exposure to perfluorooctane sulfonate during pregnancy in rat and mouse. I: Maternal and prenatal evaluations. Toxicol Sci 74:369-381.

Tyler CR, Sumpter JP, Bromage NR. 1988. In vivo ovarian uptake and processing of vitellogenin in the rainbow trout Salmo gairdneri. J Exp Zool 246:171-179.

Van de Vijver KI, Hoff PT, Das K, Van Dongen W, Esmans EL, Jauniaux T, Bouquegneau JM, Blust R, de Coen W. 2003. Perfluorinated chemicals infiltrate ocean waters: Link between exposure levels and stable isotope ratios in marine mammals. Environ Sci Technol 37:5545-5550.

Wallington TJ, Hurley MD, Xia J, Wuebbles DJ, Sillman S, Ito A, Penner JE, Ellis DA, Martin J, Mabury SA, Nielsen OJ, Sulbaek Andersen MP. 2006. Formation of $\mathrm{C}_{7} \mathrm{~F}_{15} \mathrm{COOH}$ (PFOA) and other perfluorocarboxylic acids during the atmospheric oxidation of 8:2 fluorotelomer alcohol. Environ Sci Technol 40:924-930.

Wei Y, Dai J, Liu M, Wang J, Xu M, Zha J, Wang Z. 2007. Estrogen-like properties of perfluorooctanoic acid as revealed by expressing hepatic estrogen-responsive genes in rare minnows (Gobiocypris rarus). Environ Toxicol Chem 26:2440-2447. 